\title{
The Role of Bonus Allocation in Project Investment: An Experimental Study using Balanced Scorecard (BSC) Training Treatment
}

\author{
Fauziah Rahman \\ Faculty of Economics and Business \\ Universitas Padjajaran \\ Harry Suharman \\ Faculty of Economics and Business \\ Universitas Padjajaran \\ Sofik Handoyo \\ Faculty of Economics and Business \\ Universitas Padjajaran
}

\begin{abstract}
This research aims to determine the role of bonus allocation and balanced scorecard training in the selection of investment projects. This research used a controlled laboratory experiment method with a pretest-posttest control group experimental design, which involves two groups, namely the experimental group and the control group. The experiment was carried out on 46 accounting graduate students as participants. The results of this research indicate that in selecting the investment projects, participants tend to comply with the bonus allocation policies and that balanced scorecard training is capable of predisposing participants to select projects that are oriented to long-term benefits by observed to financial and non-financial aspects. This research is specifically expected to contribute in the form of an illustration to the company about the importance of training related to the concepts and assignment techniques as well as an overview of the importance of providing appropriate bonus allocation bases to improve employee performance and evade opportunistic behavior.
\end{abstract}

Keywords: Balanced Scorecard, Bonus, Training, Investment Projects.

\section{Introduction}

Investment has a significant role in the financial world to achieve sustainable development in a company because it is often interpreted as a 'capital investment,' in which the use of investments is made regularly according to the needs of the company. Capital investment is one type of investment that is frequently studied. In determining the decision making for projects, authorization is usually given to the top-level management based on significant funding needs with a long-term orientation.

Discussion about project investment decision making analysis tools in management accounting and financial management literature places more emphasis on financial aspects such as payback periods, accounting rate returns, net present value, internal rate of return (Choi, 2014). Meanwhile, minimizing the failure of project investment also requires an analysis of non-financial aspects such as the readiness and availability of the entire resource, the market target to be addressed, and the process to be chosen for project completion. One method that can be used in decision making that focuses on financial and non-financial aspects is the balanced scorecard, e.g., research conducted by Carmona, Iyer, \& Reckers, (2011); Faizza, Purnomosidhi, \& Baridwan, (2018) who used the balanced scorecard as an approach in making investment decisions.

Several research on the balanced scorecard states that needed the compatibility between performance measurement, organizational goals and reward systems (Libby, Salterio, \& Webb, 2004; Roberts, Albright, \& Hibbets, 2004), therefore, to fulfill the organization goals in implementing balanced scorecard is always associated 
providing incentives or bonus (Cardinaels \& van Veen-Dirks, 2010; Perkins, Grey, \& Remmers, 2014; Wynder, 2010). Providing incentives or bonuses have a significant impact on increasing the motivation of employees who generally expect feedback from the company to fulfill their life needs (Alfandi \& Alkahsawneh, 2014; Danish \& Usman, 2010; San, Theen, \& Heng, 2012).

Balanced scorecard performance measurement is not only affected by bonuses and incentives but also accounting knowledge, professional experience, and the purpose of using the balanced scorecard (Porporato, 2011). Project investment decision making with a balanced scorecard approach, therefore, requires an understanding of the balanced scorecard. Waal \& Jansen (2013) revealed that cognitive motive in the form of knowledge is one of the most substantial matters affecting one's behavior in decision making. Previous empirical study has shown that knowledge and understanding of decision making are essential for making decisions, as knowledge-based decision-makers are considered to be able to make the right decisions (Malina \& Selto, 2015; Agusti \& Pertiwi, 2013; Sutedjo \& Mangkunegara, 2013).

Base on the discussion above, we identified the following problems: 1) Does the bonus allocation have a role in the decisionmaking of project investment? 2) Does the balanced scorecard training have a role in the decision-making of project investment? 3) Is the balanced scorecard training capable of affecting participants to consider the overall perspective of the BSC rather than projects that merely focus on the financial aspects in the decision-making of the project investment?

\section{Literature Review and Hypothesis Development}

\section{Balanced Scorecard}

BSC was first introduced as a measurement of financial and non-financial performance with these four perspectives (Kaplan \& Norton, 1992; Robert \& Norton, 1996): (1) financial perspective emphasizes financial objectives by measuring economic performance in terms of financial outcomes, e,g. profitability, return on investment; (2) customer perspective translates customer service mission into more specific objectives, namely customer focus, e.g., consumer satisfaction index, and market share; (3) internal business process perspective defines focus on the company's internal operations to increase shareholder value, e.g., innovation and sales services; (4) learning and growth perspective examines the importance of a business organization in monitoring wellbeing and increasing knowledge of human resources in a sustainable manner, e.g., technology adoption indices and employee development indices. A Balanced Scorecard is a management approach that enables an organization to clarify a vision, develop, and communicate strategies to achieve the vision and translate such a vision into action. One of the objectives of the BSC is to minimize or eliminate the dysfunctional behavior of management in decision making, particularly in terms of short-term financial performance (Carmona, Iyer, \& Reckers, 2011).

\section{Bonus Allocation}

Bonus allocation is associated with project investment decision making based on agency theory, which describes the relationship that occurs between the principal and the agent in the context of a contract where the principal employs the agent to provide the service and then delegates the decision-making authority to the agent (Jensen \& Meckling, 1976). The relationship between principals and agents can cause problems, as the interests of principals and agents often contradict one another (agency problem).

One efficient contract between the principal and the agent is compensation (Hladchenko, 2015), therefore in order to avoid the occurrence of agency problems, an adequate bonus allocation is needed to support the company objectives. It is also supported by the positive accounting theory (Bonus Plan Hypothesis), which states that monetary compensation is associated with management actions, and a bonus allocation is a form of compensation for agents (Watts, Zimmerman, $\&$ Ross Watts, 1978). Hence, company managers with individual bonus plans tend to prefer accounting methods that can maximize the bonus (Healy, 1985; Lev, 1979). 
When associating project investment decision making with the BSC approach, it is a fault to assess the allocation of bonuses based on financial performance (Robert \& Norton, 1996), as this can trigger opportunistic actions by managers who want to maximize their bonuses. Managers tend to merely observe the prospective investment projects in financial terms and ignore non-financial aspects, which are not in line with the objectives of the BSC. One of the conditions needed to support the successful implementation of BSC in project investment decision making is to associate rewards in the form of individual incentives to BSC performance (Lipe \& Salterio, 2000). It is essential to explain why management must support the implementation of the BSC (Olve, Petri, Roy \& Roy, 2003). Luthans (2012) argued that incentives can be used as a means to motivate employees to improve their performance and loyalty to the company. Therefore, the first hypothesis is formulated as follows:

Hypothesis 1: Bonus allocation has a role in project investment decision making.

\section{Balanced Scorecard Training}

The project investment decision-making process with a balanced scorecard approach requires decision-makers with an adequate understanding of the BSC itself. Lack of understanding of the balanced scorecard may affect one's behavior in making decisions. According to Waal \& Jansen (2013), knowledge is one factor that originates from within the employee (internal) that can affect employee behavior. Furthermore, measurement using the balanced scorecard is not only affected by bonuses and incentives but also accounting knowledge, professional experience, and the purpose of using the balanced scorecard (Porporato, 2011).

The cognitive learning theory states that the learning process is not only behavioral activity that can be directly observed but also a mental activity that includes motivation, belief, and gaps (Lardner, 2015; Massingham \& Tam, 2015). It means that even if someone has experienced the learning process, decision making is not only affected by the learning and someone who has learned has the right to decide whether to accept or reject the learning. In this study, participants were provided with the transfer of knowledge about BSC through a learning process in the form of BSC training which was only given to the experimental group. Following this, a posttest was held to determine the effectiveness of balanced scorecard training in project investment decision making. We predict that the knowledge factor has an impact on decision making. Therefore, the second hypothesis is formulated as follows:

Hypothesis 2: Balanced scorecard training has a role in project investment decision making

According to cognitive learning theory, learning is a mental event, although someone has experienced the learning process, decision making is not only affected by the learning, and someone who has learned has the right to decide whether to accept or reject the learning. Attribution Theory states that there are two causes for the behavior of others or oneself, namely dispositional attributions originating from within the individual, i.e., personality, motivation or ability, and situational attributions derived from external factors associated with social impacts from others (Luthans, 2012). Therefore, even though they have received a good understanding, other causes in decision making enable a person not to choose a good project by paying attention to all aspects as the balanced scorecard is learned. However, by looking at the results of previous studies (S. Bonner, 1990; Dearman \& Shields, 2001; Dilla \& Steinbart, 2005), it is indicated that a better understanding of knowledge related to the assignments can improve decision-makers judgment. Therefore, the hypothesis is formulated as follows:

Hypothesis 3: The balanced scorecard training affects the participants to consider the overall perspective of the BSC rather than projects that focus solely on the financial aspects of project investment decision making.

\section{Methods}

This research consists of two independent variables, i.e., bonus allocation and balanced scorecard training and one dependent variable, i.e., the project investment decision making. 
This research used the pretest-posttest control group experimental design by involving two groups, namely the experimental group and the control group. In this experiment, two tests were carried out, namely before the treatment (pretest) and after the treatment (posttest), the design of this experiment is illustrated in table 1.

Table 1. Pre-Test and Post-Test Group Research Design

\begin{tabular}{cccc}
\hline Group & Pretest & treatment & Postest \\
\hline Experiment & Y1 & $\mathrm{X} 1$ & Y2 \\
Control & Y1 & - & Y2 \\
\hline
\end{tabular}

Both the control group and the experimental group were provided with a caseby-case illustration referring to the study (Carmona et al., 2011). The financial focus used return on investment, the marketing focus used customer satisfaction, the internal environment focus uses the environmental/liability index, and the innovation focus used technology adoption index. In this experiment, these are the three types of projects with different specifications:

1) Project $A$ and $X$ have a relatively balanced value between one focus to the other, and the aggregate total value is higher than the first project (S) ;

2) Project $B$ and $Y$ have financial advantages only (the highest ROI value compared to the other two projects) but has the smallest aggregate total value $(\mathrm{F})$

3) Project $\mathrm{C}$ and $\mathrm{Z}$ have the most substantial aggregate total value compared to the other two projects but with the smallest ROI value $(\mathrm{T})$.

Projects A, B, and C were provided at the time of the pretest, while projects $\mathrm{X}, \mathrm{Y}$ and $\mathrm{Z}$ were given at the time of the posttest. The characteristics of the project were made different in order to determine the tendency of participants to make decisions after being given an understanding of the balanced scorecard. The three projects are assessed using a numerical scale from 0 to 10 , and the following assessment can be interpreted as follows: value $0=$ no support at all $; 5=$ medium support; $10=$ enthusiastic support.

Bonus allocation as an independent variable is the within-subject in this research, which is used as additional information in the project illustration in the form of a policy based on a reward for each division. It includes: (1) Annual bonus is determined based on the achievement of division performance in achieving the criteria of return on investment (ROI), customer satisfaction, environmental index, and technology adoption index or focus on all results on each criterion; (2) Division annual bonus is determined based solely on the achievement of division performance on ROI criteria or focusing only on financial outcomes. Balanced scorecard training as an independent variable is the between-subjects in this research, i.e., a treatment that is given only to the experimental group and not to the control group.

\section{Sampling}

The research included 46 participants who were postgraduate students of accounting majors at Universitas Padjajaran, Bandung, Indonesia. Sampling was carried out using the persuasive sampling method with the following sample criteria: individuals who have taken a course on the BSC concept, individuals with work experience, and individuals who have never attended a BSC training.

The selection of the criteria aims to avoid any assessment bias towards investment projects. Participants in this research are surrogates from investment managers who are the actual research subjects. The use of advanced accounting students as surrogates can be made based on common domain knowledge with professional accountants and managers (Mortensen, Fisher, \& Wines, 2012) ;(Trottier \& Gordon, 2018).

\section{Experiment Scenario}

The research was conducted in the following stages: (1) Firstly, participants with a total of 46 people gathered in the same room. We then deliver a speech and a brief introduction. We also explained the procedure of activities from the start of the event to the end and asked the participants to be able to commit 
to engaging in the activity until the end of the session. (2) We divided the participants into two groups with the same total of 23 participants for the control group and 23 participants for the experimental group. The division of the group is conducted by a random assignment, which is designed to ensure that each group has an equal level of intelligence, gender, education, and work experience before the manipulation in the research. (3) We invited the participants to fill in the demographic sheets, (4) We conducted the pretest in the form of case illustrations referring to the research (Carmona et al., 2011), (5) We provided experimental measures in the form of BSC training which is carried out only in the experimental group (6) Posttest,

Manipulation check and also (8) Closing.

\section{Internal Validity}

The internal validity of this research design is carried out in such a way that the findings obtained may be related to the treatment given. The goal of maintaining internal validity in this research are (1) to avoid selection bias by using random assignment method in grouping the participants, (2) to prevent instrument bias by providing similar instrument to the control and experimental groups (3) to avoid maturation by setting the time of the experiment as briefly as possible (4) to prevent mortality, participants are not allowed to enter and leave the room during the experiment, (5) to avoid the history effects by modifying the case illustrations given at the time of the posttest. Before the actual experiment is carried out, a pilot test is formerly conducted on 10 (ten) students aside from the participant to gain confidence that the instruments used can support the achievement of the research objectives.

\section{Analysis}

This research uses non-parametric statistical data analysis techniques due to the failure to fulfill several assumptions in the use of parametric methods. These are the conditions that cause this research data to be analyzed using non-parametric static methods: (1) Data is not normally distributed, (2) The number of samples is less than 30 for each group. It makes it impossible to process the data using parametric statistical methods even though the data is in the form of interval data (Wang \& Chee, 2012). Non-parametric statistical methods used in the analysis of this research data are Mann-Whitney $U$ test for different bonus allocation, and Wilcoxon tests for different tests before and after the balanced scorecard training is given. The software used in data analysis is the SPSS version 26. The Level of Significance $(\alpha)$ set for all tests is 0.05 or $(5 \%)$.

\section{Result and Discussion}

\section{Bonus Allocation towards Project Investment Decision Making}

The comparative test was conducted to examin hypothesis 1, in which the result is summarized in Table 2. Based on information depicted in Table 2, it can be interpreted that there are significant differences in the evaluation of each project between bonus allocation based on financial performance (ROI) and bonus allocation based on performance from the four BSC perspectives proven by Asymp value. Sig (2-tailed) at $\leq$ 0.05 .

Table 2. Comparative Test of Bonus Allocation

\begin{tabular}{lcccc}
\hline & \multicolumn{2}{c}{ Control Group } & \multicolumn{2}{c}{ Eksperiment Group } \\
\cline { 2 - 5 } Investment Project & $\begin{array}{c}\mathbf{Z} \\
\text { (Man- }\end{array}$ & $\begin{array}{c}\text { Asymp. } \\
\text { Sig.(2-tailed) }\end{array}$ & $\begin{array}{c}\text { Z } \\
\text { (Man- } \\
\text { Whitney U) }\end{array}$ & $\begin{array}{c}\text { Asymp. } \\
\text { Sig.(2-tailed) }\end{array}$ \\
\hline Proyek A(S)-Pretest & $-2,524$ & 0.012 & -3.015 & 0.003 \\
Proyek X(S)-Posttest & $-2,109$ & 0.035 & -1.112 & 0.226 \\
Proyek B(F)-Pretest & -3.902 & 0.000 & -3.321 & 0.001 \\
ProyekY(F)-Posttest & -3.736 & 0.000 & -2.425 & 0.015 \\
ProyekC(T)-Pretetest & -4.480 & 0.000 & -2.391 & 0.017 \\
ProyekZ(T)-Posttest & $-4,850$ & 0.000 & $-1,023$ & 0.304 \\
\hline
\end{tabular}

Source: Primary Data (processed by the researcher) 
There are exceptions to the posttest assessment of the experimental group in which balanced scorecard training was given, namely project $\mathrm{X}$ (project characteristics are balanced at each focus) and posttest project $\mathrm{Z}$ (project characteristics with the highest total value) with Asymp value. Sig (2-tailed) $\geq 0.05$, it can be interpreted that there are no significant differences can be explained by the following justifications: (1) Based on situational attribution theory, a person's decision making actions can be affected by external factors, posttest in the experimental group is conducted after BSC training (external factors), which may affect participants in providing investment project assessment.

Projects $\mathrm{X}$ and $\mathrm{Z}$ are projects with criteria that are based on the BSC concept, and therefore there is no difference in the assessment when bonus allocation policies are based on financial performance or based on the four BSC perspectives, (2) justification can also be based on dispositional attribution theory, originating from the participants themselves, for instance, motivation, personality, and skill, (3) Justification based on Piaget's cognitive learning theory, i.e., the mindset and behavior of a person accommodates new perceptions learned through the process of assimilation and accommodation, is what shape changes in a person due to the process of thought (Dalyono, 2012). BSC training provides the participants in the experimental group with a new understanding so that participants' assessment of investment projects tends to follow the new perceptions that have just been studied so that investment project assessments tend to lead to projects with the BSC concept of both bonus allocations based on financial aspects of ROI and the four BSC perspectives.

Based on the results of description to the comparative test of allocation bonus (table 2) as a whole, there are differences in investment project selection decisions when bonus allocations are determined based on financial performance (ROI) compared to bonus allocations determined based on performance from the four perspectives of the balanced scorecard. It can be concluded that bonus allocation has a role in project investment decision making.

The results of this research are consistent with several previous studies including (S. E. Bonner, Hastie, Sprinkle, \& Young, 2000; Carmona et al., 2011; Faizza et al., 2018; Lee, 2012) which reported that incentives play a role in decision making, or in other words, affects performance in an assignment. The results of this research are also in line with several theories, including agency theory, which states that appropriate bonus allocation can be a control medium for direct agents to act following company objectives and principle inclination, whereas improper bonus allocation can be a boomerang for the company by triggering the emergence of dysfunctional behavior that may cause problems for the company. When associated with the result of the research, when the bonus allocation is determined based on the performance of the four BSC perfective, participants tend to choose projects with an equivalent value in all four aspects of the BSC with a project orientation towards long-term benefits. Whereas when bonus allocations are set based on financial performance (ROI), participants tend to choose projects that are oriented to short-term profits, these are projects with the highest ROI values even though the three other BSC aspects are of low value and it is one example of dysfunctional behavior. This condition can also be explained by positive accounting theory in the bonus plan hypothesis which states that managers in their payroll systems are highly dependent on incentives, so managers prefer to choose investment projects that can increase their bonuses (Watts et al., 1978)

Project investment decision making before and after the implementation of BSC training

Comparative pretest-posttest was conducted to examine hypothesis 2 , in which the result is summarized in Tables 3 and Table 4. Table 3 shows that there were no significant differences between pretest and posttest in each project when bonus allocation is based on financial aspects (ROI), and the four BSC perspectives were proven by looking at the results of Asymp. Sig (2 tailed) control group $\geq$ 
0.05 . The justification given for this result is that participants in the control group did not receive BSC training so that participants in the control group tend not to change the assessment of the three investment projects at the time of the posttest. It indicates that participants in the control group did the project assessment by adjusting the bonus allocation policy.

Table 3. Pretest -Posttest of Control Group

\begin{tabular}{|c|c|c|c|c|c|c|}
\hline & & \multicolumn{5}{|c|}{ Control Group (Without BSC Training) } \\
\hline & & \multicolumn{2}{|c|}{$\begin{array}{l}\text { Bonus Allocation Based on } \\
\text { Financial Fokus (ROI) }\end{array}$} & & \multicolumn{2}{|c|}{$\begin{array}{l}\text { Bonus Allocation Based on } \\
\text { All BSC Perspectives }\end{array}$} \\
\hline & & $\begin{array}{c}\mathrm{Z} \text { (Wilcoxon } \\
\text { Signed Ranked } \\
\text { Test) }\end{array}$ & $\begin{array}{l}\text { Asymp.Sig } \\
\text {. (2-tailed) }\end{array}$ & & $\begin{array}{c}\text { Z(Wilcoxon } \\
\text { Signed Ranked } \\
\text { Test) }\end{array}$ & $\begin{array}{l}\text { Asymp.Sig } \\
\text {. (2-tailed) }\end{array}$ \\
\hline Pair 1 & $\begin{array}{l}\text { Proyek A-Pretest (S) } \\
\text { Proyek X-Posttest (S) }\end{array}$ & -0.386 & 0.700 & Pair 4 & -0.753 & 0.451 \\
\hline Pair 2 & $\begin{array}{l}\text { Proyek B-Pretest }(\mathrm{F}) \\
\text { Proyek Y- Posttest }(\mathrm{F})\end{array}$ & -1.128 & 0.259 & Pair 5 & -0.128 & 0.898 \\
\hline Pair 3 & $\begin{array}{l}\text { Proyek C-Pretest (T) } \\
\text { Proyek Z Posttest }(\mathrm{T})\end{array}$ & -0.864 & 0.388 & Pair 6 & -0.616 & 0.538 \\
\hline
\end{tabular}

Source: Primary Data (processed by the researcher)

Table 4. Pretest-Posttest of Experiment Group

\begin{tabular}{|c|c|c|c|c|c|c|}
\hline \multicolumn{7}{|c|}{ Experiment Group (With BSC Training) } \\
\hline & & \multicolumn{2}{|c|}{$\begin{array}{c}\text { Bonus Allocation Based on } \\
\text { Financial Focus (ROI) }\end{array}$} & & \multicolumn{2}{|c|}{$\begin{array}{c}\text { Bonus Allocation Based on } \\
\text { All BSC } \\
\end{array}$} \\
\hline & & $\begin{array}{l}\mathrm{Z} \text { (Wilcoxon } \\
\text { Signed Ranked } \\
\text { Test) }\end{array}$ & $\begin{array}{l}\text { Asymp. } \\
\text { Sig. (2- } \\
\text { tailed) }\end{array}$ & & $\begin{array}{l}\text { Z (Wilcoxon } \\
\text { Signed Ranked } \\
\text { Test) }\end{array}$ & $\begin{array}{l}\text { Asymp. } \\
\text { Sig. (2- } \\
\text { tailed) }\end{array}$ \\
\hline Pair 1 & $\begin{array}{l}\text { Proyek A-Pretest (S) } \\
\text { Proyek X- Posttest (S) }\end{array}$ & -2.494 & 0.003 & Pair 4 & -0.857 & 0.391 \\
\hline Pair 2 & $\begin{array}{l}\text { Proyek B-Pretest }(\mathrm{F}) \\
\text { Proyek Y- Posttest }(\mathrm{F})\end{array}$ & -2.091 & 0.037 & Pair 5 & $-1,312$ & 0.190 \\
\hline Pair 3 & $\begin{array}{l}\text { Proyek C-Pretest (T) } \\
\text { Proyek Z Posttest (T) }\end{array}$ & -2.101 & 0.051 & Pair 6 & -0.806 & 0.420 \\
\hline
\end{tabular}

Source: Primary Data (processed by the researcher)

As with the comparison of pretestposttest in the experimental group, it can be seen in Table 4 that the results of the Wilcoxon test can be interpreted as follows: (1) There are significant differences between projects with balanced characteristics in all aspects (S) and projects with superior characteristics on the financial aspect $(\mathrm{F})$ when bonus allocations are determined based on financial focus (ROI), with a significant level of 0.003 on each project; $0.037 \leq 0.05$. (2) There is no significant difference in projects with the highest total value characteristic (T) when the bonus allocation is determined based on the financial focus (ROI), with a significant level of $0.051 \geq$ 0.050 . (3) There was no significant difference in the overall project when the bonus allocation was determined based on the performance of the four BSC perspectives with a significant level of $\geq 0.050$.

The following justifications can explain the results of interpreting to the comparison of pretest-postest in the experimental group (table 4): (1) BSC training has an impact on project assessment, particularly on projects with superior characteristics in financial focus and also on balanced projects in overall focus, as projects with superior characteristics in financial focus are the most distant projects with the BSC concept and the balanced project in its overall focus are projects that are similar to the BSC concept, so that participants have understood the BSC concept and try to implement it during project assessment; (2) When bonus allocations are based on all four 
aspects of the BSC, participants tend not to change their decisions significantly. It is because bonus allocation based on the four BSC perspectives is following the BSC concept, which not only focuses on short-term profits but also long-term benefits by taking into account all aspects, so there is no difference in the pretest and posttest when bonus allocations are based on the four aspects of the BSC.

The difference in decision making between participants after receiving BSC training and before receiving $\mathrm{BSC}$ training indicates that $\mathrm{BSC}$ training plays a role in project investment decision making. Understanding of BSC gained from the training was capable of affecting the behavior of participants who initially focused on short-term projects, focusing solely on financial factors, so that they could pay more attention to the overall focus.

The results of this research are in line with cognitive learning theory that forms the basis of the theory in this study, i.e., a learning process which is the process of observing stimulus as a whole and that the learning situation also determines one's decision making compared to punishment and reward (Dalyono, 2012). When associated to the result of the research, participants in the experimental group have experienced the learning process by obtaining stimulus in the form of material provided through BSC training, and it can be concluded that participants are confident in the material that has been delivered so that participants can trust that, by choosing projects that pay attention to all aspects, they may obtain a more stable bonus allocation in the long run.

Besides, the result of this study is in line with several previous studies which have shown that the understanding of the BSC has an impact on decision making (Dilla \& Steinbart, 2005; Faizza et al., 2018). Also, according to (Cardinaels, 2008), different understandings may provide different judgment. On this basis, it can be concluded that the understanding of BSC has an impact on the behavior of participants in decision making. The detailed results that support hypothesis 2 are summarized in Table 5 below.

Table 5. Participant Trends in the Selection of Investment Projects

Selection of Investment Projects with Bonus Allocation based on ROI

\begin{tabular}{ccccccccccc}
\hline Project Criteria & \multicolumn{3}{c}{$\begin{array}{c}\text { Control Group } \\
\text { (Number of } \\
\text { Participants) }\end{array}$} & \multicolumn{3}{c}{$\begin{array}{c}\text { Experiment Group } \\
\text { (Number of Participants) }\end{array}$} \\
\cline { 2 - 10 } & Pretest & Postest & Pretest & \multicolumn{2}{c}{ Postest } \\
\hline (S) & A & 4 & $\mathrm{X}$ & 4 & $\mathrm{~A}$ & 3 & $\mathrm{X}$ & 13 \\
(F) & $\mathrm{B}$ & 17 & $\mathrm{Y}$ & 16 & $\mathrm{~B}$ & 17 & $\mathrm{Y}$ & 7 \\
(T) & $\mathrm{C}$ & 2 & $\mathrm{Z}$ & 3 & $\mathrm{C}$ & 3 & $\mathrm{Z}$ & 3 \\
\hline
\end{tabular}

Selection of Investment Projects with Bonus Allocation based on all four aspects of the BSC

\begin{tabular}{ccccccccccc}
\hline Project Criteria & \multicolumn{3}{c}{$\begin{array}{c}\text { Control Group } \\
\text { (Number of } \\
\text { Participants) }\end{array}$} & \multicolumn{3}{c}{$\begin{array}{c}\text { Experiment Group } \\
\text { (Number of Participants) }\end{array}$} \\
\cline { 2 - 10 } & Pretest & Postest & Pretest & \multicolumn{2}{c}{ Postest } \\
\hline (S) & A & 14 & X & 16 & A & 13 & X & 19 \\
(F) & B & 0 & Y & 0 & B & 1 & Y & 0 \\
(T) & C & 9 & Z & 7 & C & 9 & Z & 4 \\
\hline
\end{tabular}

Source: Primary Data (processed by the researcher)

Based on Table 5, the selection of investment projects during the pretest and posttest in the control group participants tends to choose projects based on bonus allocations, because the control group does not receive BSC training. Whereas in the experimental group before receiving balanced scorecard training (pretest), participants tend to select investment 
projects based on bonus allocations and after receiving Balanced Scorecard (posttest) training, participants tend to change their decisions and pay more attention to projects with balanced criteria in all aspects of the BSC. The results of this research are in line with research by (Dearman \& Shields, 2001; Dilla \& Steinbart, 2005) which state that a better understanding of specific knowledge about assignments may affect one's decision making to be able to provide more judgment.

\section{Conclusion}

Based on the result of the study, it is known that bonus allocation and balanced scorecard training plays a role in the decision making process for investment projects. Besides, participants who have received balanced scorecard training mostly tend to change their decision to choose projects that take into account the four perspectives of the balanced scorecard.

This research is useful for companies as empirical evidence of the importance of training in increasing knowledge and understanding of disciplines related to assignments of management decisions to act following the company objective. A balanced scorecard approach is not only used as a tool for performance evaluation but can also be used to analyze decision making in project investment selection. Moreover, this can be the empirical proof that the determination of bonus allocations based on the BSC perspectives is capable of encouraging employee performance without causing opportunistic behavior by solely focusing on short-term financial benefits and ignoring the overall sustainability process which may affect long-term profits.

There are several limitations in this research; first is the difficulties of adjusting the schedule among the research participants because the participants have their activities in the form of work, etc., that causing the number of participants who can attend to be limited. Second, the factors that affected in the investment decision making of the project in this research only consist of 2 variables, namely the bonus allocation and balanced scorecard training, while many other factors play a role in investment decision making, such as the type of decision making, motivation to learn etc.
Suggestions from the authors for further research are, increasing the number of the research participants, among them by making a written contract with the participants who can attend so that there is agreement on the schedule, time and place of the research. Make attractive door prizes to motivate participants to participate in a whole series of research activities. Furthermore, the last is the addition of a variable type of decision making and learning motivation to clarify further the basis of decision making by the participants.

\section{References}

Alfandi, D. A. M., \& Alkahsawneh, D. M. S. (2014). The Role of the Incentives and Reward System in Enhancing Employee's Performance: Case of Jordanian Travel and Tourism Institutions". International Journal of Academic Research in Business and Social Sciences, 4(4), 326341. https://doi.org/10.6007/ijarbss/v4i4/788

Bonner, S. (1990). Experience Auditing: The Effects Role in of Knowledge TaskSpecific. The Accounting Review, 65(1), 72-92. https://doi.org/10.1021/ol8009682

Bonner, S. E., Hastie, R., Sprinkle, G. B., \& Young, S. M. (2000). A Review of the Effects of Financial Incentives on Performance in Laboratory Tasks: Implications for Management Accounting. Journal of Management Accounting Research. https://doi.org/10.2308/jmar.2000.12.1.1 9

Cardinaels, E. (2008). The interplay between cost accounting knowledge and presentation formats in cost-based decision-making. Accounting, Organizations and Society, 33(6), 582602.

https://doi.org/10.1016/j.aos.2007.06.003

Cardinaels, E., \& van Veen-Dirks, P. M. G. (2010). Financial versus non-financial information: The impact of information organization and presentation in a Balanced Scorecard. Accounting, 
Organizations and Society, 35(6), 565578.

https://doi.org/10.1016/j.aos.2010.05.003

Carmona, S., Iyer, G., \& Reckers, P. M. J. (2011). The impact of strategy communications, incentives and national culture on balanced scorecard implementation. Advances in Accounting, 27(1), $62-74$. https://doi.org/10.1016/j.adiac.2011.01.0 04

Choi, J. (2014). Can offering a signing bonus motivate effort? Experimental evidence of the moderating effects of labor market competition. Accounting Review, 89(2), 545-570. https://doi.org/10.2308/accr50641

Dalyono, M. (2012). Psikologi Pendidikan (7th ed.). Jakarta: Rineka Cipta.

Danish, R. Q., \& Usman, A. (2010). Impact of Reward and Recognition on Job Satisfaction and Motivation: An Empirical study from Pakistan. International Journal of Business and Management, 5(2), 159-167. https://doi.org/10.5539/ijbm.v5n2p159

Dearman, D. T., \& Shields, M. D. (2001). Cost Knowledge and Cost-Based Judgment Performance. Journal of Management Accounting Research. https://doi.org/10.2308/jmar.2001.13.1.1

Dilla, W. N., \& Steinbart, P. J. (2005). Relative Weighting of Common and Unique Balanced Scorecard Measures by Knowledgeable Decision Makers. Behavioral Research in Accounting. https://doi.org/10.2308/bria.2005.17.1.43

Faizza, M., Purnomosidhi, B., \& Baridwan, Z. (2018). Peran Alokasi Bonus Dan Pemahaman Balanced Scorecard Dalam Pemilihan Proyek Investasi. Jurnal Akuntansi Multiparadigma, 9(3), 437450.

https://doi.org/10.18202/jamal.2018.04.9 026

Healy, P. M. (1985). The effect of bonus schemes on accounting decisions. Journal of Accounting and Economics, 7(1-3), 85-107. https://doi.org/10.1016/01654101(85)90029-1

Hladchenko, M. (2015). Balanced Scorecard A strategic management system of the higher education institution. International Journal of Educational Management, 29(2), 167-176. https://doi.org/10.1108/IJEM-11-20130164

Jensen, M. ., \& Meckling, W. (1976). Theory of the Firm Managerial Behavior, Agency Costs and Ownership Structure. Journal of Financial Economics.

Kaplan, R. S., \& Norton, D. P. (1992). The balanced scorecard--measures that drive performance. Harvard Business Review.

Lardner, S. (2015). Effective reward ensures effective engagement. Strategic $H R$ Review, 14(4), 131-134. https://doi.org/10.1108/shr-06-2015-0050

Lee, H. (2012). Incentive contracts and time pressure on audit judgment performance. Managerial Auditing Journal, 27(3), 263283.

https://doi.org/10.1108/02686901211207 492

Lev, B. (1979). on Impact the Oil of Accounting Market: The Regulation Case of Gas Companies. American Accounting Association, 54(3), 485-503.

Libby, T., Salterio, S. E., \& Webb, A. (2004). The balanced scorecard: The effects of assurance and process accountability on managerial judgment. Accounting Review.

https://doi.org/10.2308/accr.2004.79.4.10 75

Lipe, M. G., \& Salterio, S. E. (2000). The Balanced Scorecard: Judgmental Effects of Common and Unique Performance Measures. 75(3), 283-298.

Luthans, F. (2012). Organisational Behaviour: An Evidence-Based Approach. In Organizational Behavior: An evidenceBased Approach (12th ed.). McGraw-Hill. 
Malina, M. A., \& Selto, F. H. (2015). Behavioral-economic nudges and performance measurement models. Journal of Management Accounting Research. https://doi.org/10.2308/jmar50821

Massingham, P. R., \& Tam, L. (2015). The relationship between human capital, value creation and employee reward. Journal of Intellectual Capital, 16(2), 390-418. https://doi.org/10.1108/JIC-06-20140075

Mortensen, T., Fisher, R., \& Wines, G. (2012). Students as surrogates for practicing accountants: Further evidence. Accounting Forum, 36(4), 251-265. https://doi.org/10.1016/j.accfor.2012.06.0 03

Perkins, M., Grey, A., \& Remmers, H. (2014). What do we really mean by "Balanced Scorecard"? International Journal of Productivity and Performance Management, 63(2), 148-169.

Porporato, M. (2011). Balanced Scorecard Design Preferences According to Subjects' Expertise and Purpose of Use. SSRN Electronic Journal. https://doi.org/10.2139/ssrn.1003863

Robert, D. K., \& Norton. (1996). Management to Strategy Scorecard to Strategy. California Management Review, 39(1), 53-79.

Roberts, M. L., Albright, T. L., \& Hibbets, A. R. (2004). Debiasing Balanced Scorecard Evaluations. Behavioral Research in Accounting. https://doi.org/10.2308/bria.2004.16.1.75

San, O. T., Theen, Y. M., \& Heng, T. B. (2012). The Reward Strategy and Performance
Measurement ( Evidence from Malaysian Insurance Companies ). International Journal of Business, Humanities and Technology, 2(1), 211-223.

Sutedjo, A. S., \& Mangkunegara, A. P. (2013). Pengaruh Kompetensi dan Motivasi Kerja terhadap Kinerja Karyawan di PT. Inti Kebun Sejahtera. Jurnal Bisnis Dan Manajemen, 5(2), 120-129.

Trottier, K., \& Gordon, I. M. (2018). Students as surrogates for managers: Evidence from a replicated experiment. Canadian Journal of Administrative Sciences, 35(1), 146-161. https://doi.org/10.1002/cjas.1377

Waal, A. de, \& Jansen, P. (2013). The bonus as hygiene factor : the role of reward systems in the high performance organization. Evidence-Based HRM: A Global Forum for Empirical Scholarship, 1(1), 41-59. https://doi.org/10.1108/20493981311318 601

Wang, Y., \& Chee, C. (2012). Density estimation using non-parametric and semi-parametric mixtures. Statistical Modelling, 12, 67-92.

Watts, R. L., Zimmerman, J. L., \& Ross Watts, S. L. (1978). Towards a Positive Theory of the Determination of Accounting Standards Towards a Positive Theory of the Determination of Accounting. Source: The Accounting Review, 53(I), 112-134. Retrieved

Wynder, M. (2010). Evaluating performance based on the Balanced Scorecard. Journal of Accounting Education, 28(3-4), 221236.

https://doi.org/10.1016/j.jaccedu.2011.03 .006 